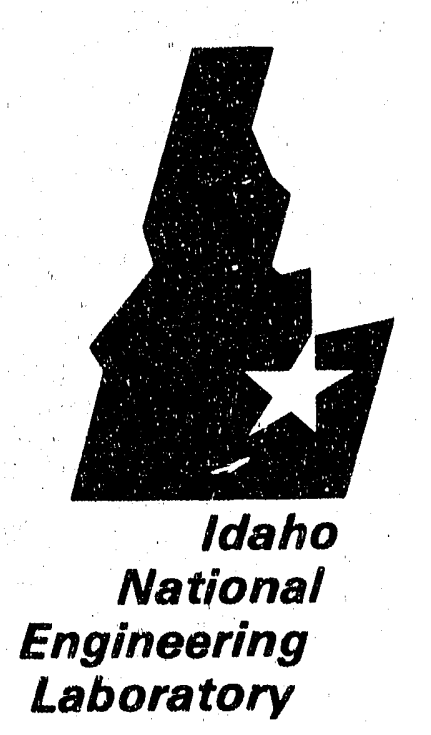

EGG-WTD-9800, Rev. 0

February 1992

\section{Arte?}

Buried Waste Integrated

Demonstration Program Technology Test Plan Guidance

J. K. Rehwaldt

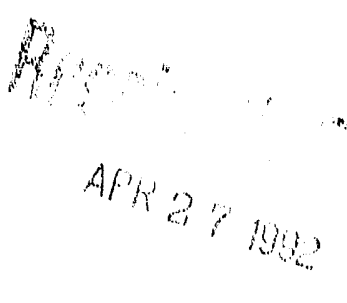

\author{
Managed \\ by the U.S. \\ Department \\ of Energy
}


This document contains new concepts or the author(s) interpretation of new calculations and/or measurements; accordingly, EG\&G Idaho. Inc. is required by the United States Goverriment to include the following disclaimer:

\section{DISCLAIMER}

This report was prepared as an account of work sponsored by an agency of the United States Government. Neither the United States Government nor any agency thereot, nor any of their employees, makes any warranty, express or implied, or assumes any legal liability or responsibility for the accuracy, completeness, or usefulness of any information, apparatus, product or process disclosed, or represents that its use would not infringe privately owned rights. References herein to any specific commercial product, process, or service by :rade name, trademark, manufacturer, or otherwise, does not necessarily constitute or imoly its endorsement, recommendation, or favoring by the United States Government or any agency thereot. The views and opınions of authors expressed herein do not necessarily state or reflect those of the United States Government or any agency thereot. 


\section{Buried Waste Integrated Demonstration Program Technology Test Plan Guidance}

J. K. Rehwaldt

Published February 1992

Idaho National Engineering Laboratory

EG\&G Idaho, Inc.

Idaho Falls, Idaho 83415

\section{Prepared for the}

U.S. Department of Energy

Office of Environmental Restoration and Waste Management

Under DOE Idaho Field Office

Contract DE-AC07-761001570 
EGG-WTD-9800, Rev. 0 February 1992

\section{Buried Waste Integrated Demonstration Program Technology Test Plan Guidance}
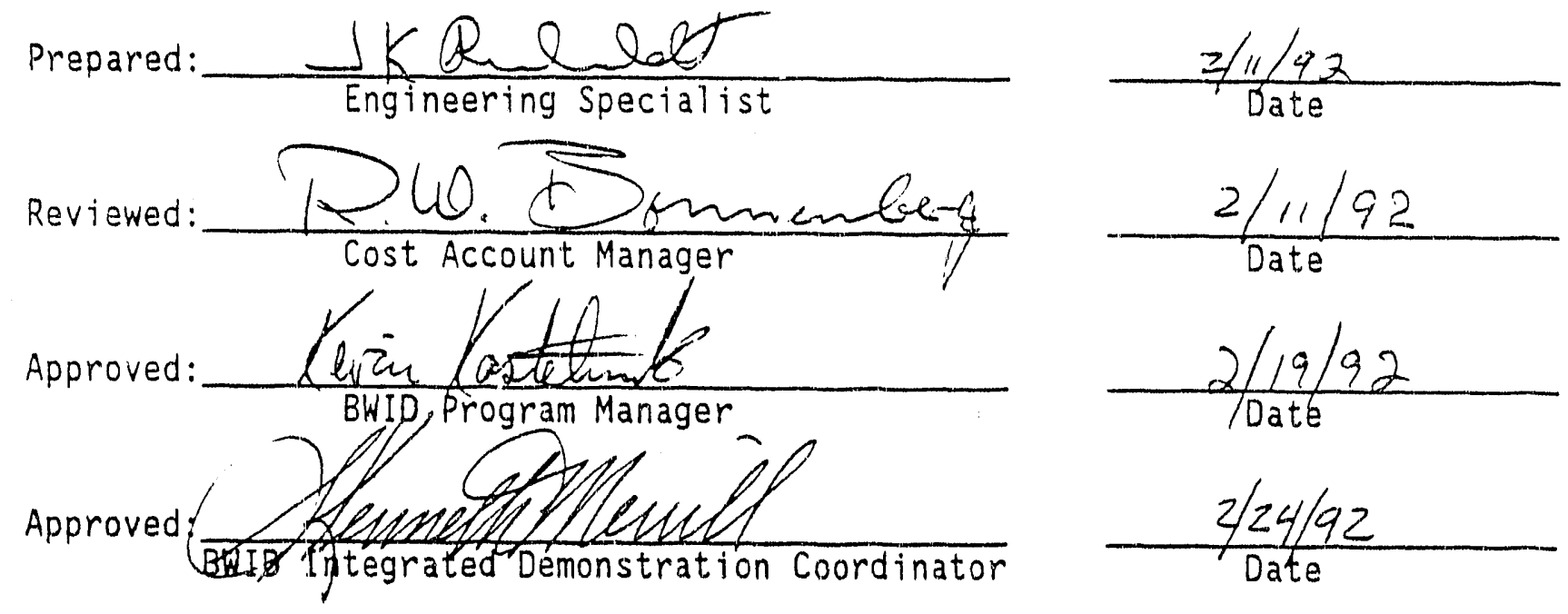
EGG-WTD-9800, Rev. 0 February 1992

\section{ABSTRACT}

The Technology Test Plan Guidance provides instructions for principal investigators preparing test plans to demonstrate technologies supported by the Buried Waste Integrated Demonstration Program. 
EGG-WTD-9800, Rev. O

February 1992 
EGG-WTD-9800, Rev. 0 February 1992

\section{CONTENTS}

ABSTRACT ..................................... i

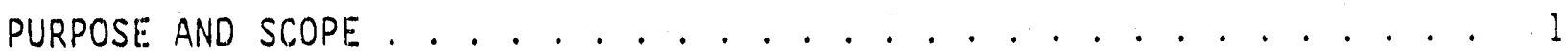

POLICY . . . . . . . . . . . . . . . . . . . . . 1

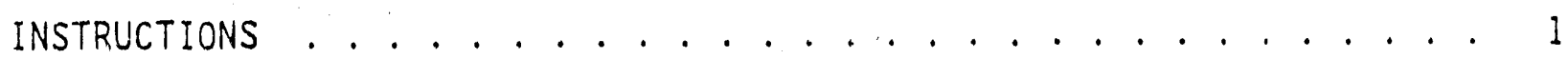

REFERENCES . . . . . . . . . . . . . . . . . . . . . . 2

APPENDIX A--Technology Test Plan Guidance. . . . . . . . . . . . . A-1 
EGG-WTD-9800, Rev. O

February 1992

\title{
BURIED WAste INTEgRATEd DEMONSTRATION PROGRAM TECHNOLOGy TEST Plan Guidance
}

\author{
PURPOSE AND SCOPE
}

The Technology Test Plan Guidance provides instructions for preparing test plans to demonstrate technologies supported by the Buried Waste Integrated Demonstration Program. The mission of the Buried Waste Integrated Demonstration Program is to demonstrate and evaluate technologies that are potentially faster, better, cheaper, and/or safer for application to buried waste restoration. The purpose of the technology tes'c plan is to ensure that useful, quality data are collected. The technology test plan should be written to reflect Buried Waste Integrated Demonstration Program's mission and to ensure the data collected by the test is useful for the Department of Energy Environmental Restoration Program.

\section{POLICY}

Organizations performing demonstrations shall submit a written test plan as outlined by this document. The test plan shall support the technical task plan or the Cooperative Research and Development Agreement under which it is developed. The test plan shall be approved by BWID and personnel with expertise in safety, quality, regulatory requirements, and operations for the host site demonstration.

\section{INSTRUCTIONS}

Plans should be developed for a complete test. The test plan shall include the following sections:

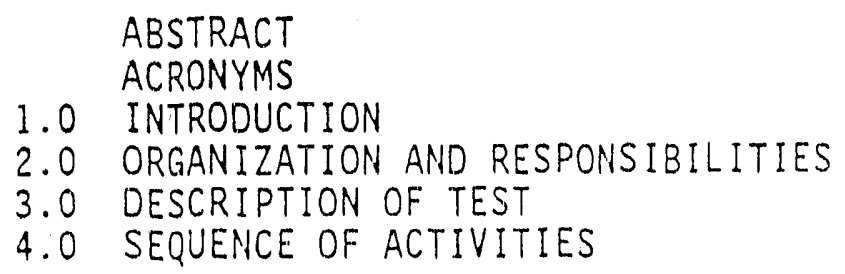


5.0 SAMPLING/DATA

6.0 DOCUMENT CONTROL

7.0 ANALYTICAL METHODS

8.0 DATA REDUCTION AND VALIDATION

9.0 QUALITY ASSURANCE

10.0 EQUIPMENT AND INSTRUMENTS

11.0 SUPPLIES AND UTILITIES

12.0 HEALTH AND SAFETY

13.0 RESIDUALS MANAGEMENT

14.0 REFERENCES

15.0 APPENDICES

All sections must be addressed, even though for smaller activities sections may be simplified. If any of the sections are not applicable, the heading shall be included with the statement, "This section is not applicable."

\section{REFERENCES}

1. EG\&G Idaho, Environmental Restoration Program, Program Directives, 5.10, "Test Plans", July 12, 1991.

2. U.S. Environmental Protection Agency, Office of Research and Development, Cincinnati, Ohio 45268, and Office of Emergency and Remedial Response, Washington, D.C. 20460, Guide for Conducting Treatability Studies Under CERCLA (Interim Final), EPA/540/2-89/058, December 1989.

3. United States Environmental Protection Agency, Office of Monitoring Systems and Quality Assurance, Office of Research and Development, Washington, D.C. 20460, Interim Guidelines and Specifications for Preparing Quality Assurance Project Plans, EPA-QAMS-005/80, December 29, 1980. 
EGG-WTD-9800, Rev. O February 1992

APPENDIX A

TECHNOLOGY TEST PLAN GUIDANCE

$A-1$ 
EGG-WTD-9800, Rev. O

February 1992 
EGG-WTO-9800, ReV. O

February 1992

\author{
APPENDIX A \\ TECHNOLOGY TEST PLAN GUIDANCE
}

\title{
ABSTRACT
}

Briefly discuss the technology demonstration, objectives, sequence of activities, and equipment.

\section{ACRONYMS}

List the acronyms and abbreviations used and the words they represent.

\subsection{INTRODUCTION}

1.1 Technology Description and Background.

1.2 Scope of test. Define the subject area of the test and provide a brief description.

1.3 Objective of Test. State the purpose or the hypothesis of the test, type of information the test will furnish, and the data quality objectives being addressed, if applicable.

1.4 Technology Agreement. Define the technology agreement with BWID. This may be as simple as identifying the technical task plan or the Cooperative Research and Development Agreement the demonstration was developed by.

\subsection{ORGANIZATION AND RESPONSIBILITIES}

2.1 Show a chart defining organizational responsibilities; include subcontractors, if used.

2.2 Describe the responsibilities of the organization conducting the test and the delegation of authority for conducting the test.

2.3 Indicate personnel support requirements, including monitoring and surveillance, as needed.

2.4 List the required test personnel qualifications and level of training. 
EGG-UTD-9800, Rev. D

February 1992

\section{D DESCRIPTION OF TEST}

NOTE: Sufficient data should be collected by the test to address the requested estimates in Table 1 (attached). The information requested in Table 1 will be reported in the Technology Evaluation Report. This information will be used to evaluate the technology for full scale operation.

3.1 Define the key input and output parameters measured and the test conditions.

3.2 List the number of tests, location, duration, and schedule.

3.3 Describe the test method and uncertainties.

3.4 Identify the procedures to conjuct the test, documents to be prepared detailing the procedures (i.e., detailed operating procedures, etc), and applicable prerequisites, including regulatory documentation.

3.5 Include illustrations to assist in understanding the test.

3.6 State the contingency plan(s). Explain how implementing the contingency plan would affect test and quality objectives. Contingency plans may be presented in a logic diagram format.

3.7 List the performance objectives.

\subsection{SEQUENCE OF ACTIVITIES}

Describe the order in which activities will occur, detailed schedule of the test, and its associated activities/analysis. Indicate milestones and decision points.

\subsection{SAMPLING AND DATA}

5.1 Describe the data collection techniques or guidelines used to collect test data.

5.2 Specify sampling and data collection procedures.

5.3 The Sampling and Analysis Plan should be part of the Technology Tes: Plan. If the Sampling and Analysis Plan is a subset of a larger demonstration, then reference the applicable Sampling and Analysis plan. 
EGG-WTD-9800, Rev, O

February 1992

\subsection{DOCUMENT CONTROL}

6.1 Data. Describe how the data will be documarted, controlled, and stored. If a database management system is used, include the frequency and method of data backup.

6.2 Test Plan. Explain how changes to the test plan will be documented, reviewed, and approved. This can be as simple as referring to an applicable procedure or configuration management plan that explains changes to documents.

6.3 Other documents. Describe document control methods for other documents used to perform the test, such as operating procedures, $\log$ books, etc.

\subsection{ANALYTICAL METHODS}

Describe the analytical method(s) to be used. Reference standard methods and include copies of all other methods.

\subsection{DATA REDUCTION, VALIDATION, AND VERIFICATION}

8.1 Describe the data reduction sc.,eme, including all equations used to calculate the measured parameter and reporting units.

8.2 Define how the data that are collected are validated.

8.3 State who is responsible for validating the data.

8.4 List and define the acceptance criteria. Explain how the acceptance criteria was derived.

\subsection{QUALITY ASSURANCE}

Quality Assurance will help ensure the data that are collected for a Buried Waste Integrated Demonstration Program demonstration are good, meaningful data.

9.1 State the quality level, inspection requirements, and the applicable quality program plan the test will adhere to. Address how nonconformance will be resolved. 
EGG-WTD-9800, Rev. O

February 1992

9.2 Describe and/or reference all specific quality control methods to be followed. Examples of items to be considereo are replicates, spiked samples, split samples, control charts, blanks, and surrogate samples.

9.3 Describe the routine procedures used to assess the precision, accuracy, and completeness of the measured data. These procedures should include the equations to calculate precision, accuracy, completeness, and uncertainty.

9.4 Describe the internal audit system to verify that the nroposed procedures are followed.

\subsection{EQUIPMENT AND INSTRUMENTS}

10.1 List the equipment and instruments required to run the test and who will furnish the equipment and instruments.

10.2 Define range, accuracy, and tolerance requirements for the equipment and instruments.

19.3 Describe the calibration or standardization procedure(s) for the equipment and instruments and include the frequency the procedures will be performed.

10.4 Define a preventive maintenance schedule for the equipment and instruments to minimize down-time. Include a list of critical spare parts.

\subsection{SUPPLIES, UTILITIES, AND FACILITIES}

Address the required supplies, utilities, and facility support to perform the test. Include who will provide them.

\subsection{HEALTH AND SAFETY}

Identify the health and safety measures to ensure the health and safety of the operators and the surrounding community. This may be as simple as referencing the Regulatory Compliance Plan. 
EGG-WTD-9800, Rev. O February 1992

\subsection{RESIDUALS MANAGEMENTS}

Describe the type of waste by-products generated by the demonstration. Include the volume generated, physical state, and how the by-products will be disposed of.

\subsection{REFERENCES}

List all references cited in the test plan.

\subsection{APPENDICES}

The appendices should include the detailed operating procedures, standard operating procedures, and any other required documents. 
a. Operation and maintenance cost for the life cycle of the technology demonstrated. Operation and maintenance cost includes storage and disposition of waste, operation of equipment (manpower, electrical power, etc) and maintenance (cost of replacement parts, manpower, etc), and decommissioning.

b. Acquisition cost, including capital.

c. Volume $\left(\mathrm{m}^{3}\right)$ of input material, toxicity level, mobility, and physical state.

d. Volume $\left(\mathrm{m}^{3}\right)$ of contaminated material produced (gloves, bags, tools, process water, etc), and physical state.

e. Time to remediate the input volume.

f. Time to remediate $50 \%$ of the input volume.

g. List the process output, their waste classification, concentration or activity, toxicity level, mobility, and volume $\left(\mathrm{m}^{3}\right)$.

h. T'me until line item and capital equipment replacement costs exceec $50 \%$ of acquisition cost.

i. Number of commercial off-the-shelf subelements. A subelement consists of one or more integrated components assembled to perform a function whose performance can be specified from the system functional and operational requirements.

j. Total number of custom subelements.

k. Time for scheduled maintenance.

1. Time for unscheduled maintenance.

m. Time from now to field demonstration. Now is considered to be the approval date of the technical evaluation report.

n. Time from now to full scale operation. 
EGG-WTD-9800, Rev. 0 February 1992

\section{TABLE 1 (Contd)}

o. Mean years of specialized training required for full-scale operation (academic and facility specific).

p. Labor hours per hour of operation.

q. Time for the replacement parts to exceed $50 \%$ of the acquisition costs.

$r$. The list of permits required for a full-scale operation.

s. Time to construct or fabricate the equipment necessary to operate the process.

t. Types and quantities of utilities (water, electricity, etc) required during the process. 

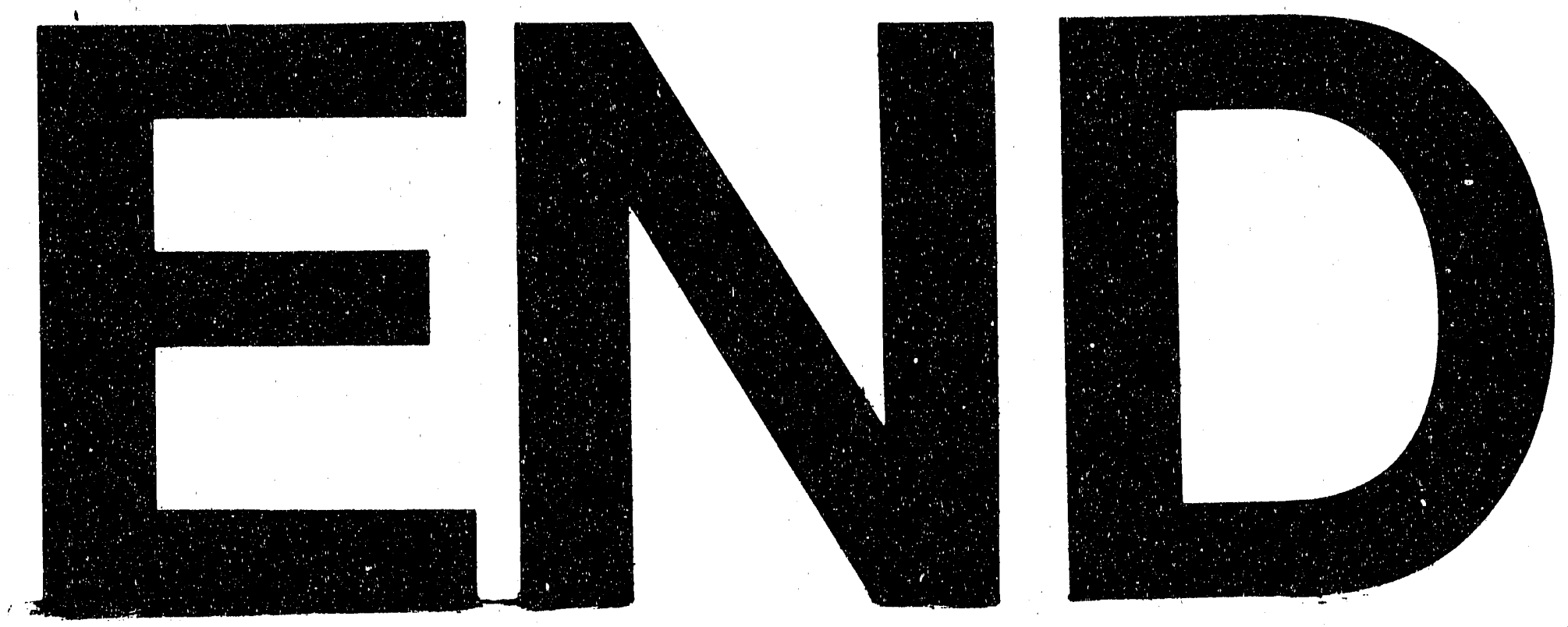

3.

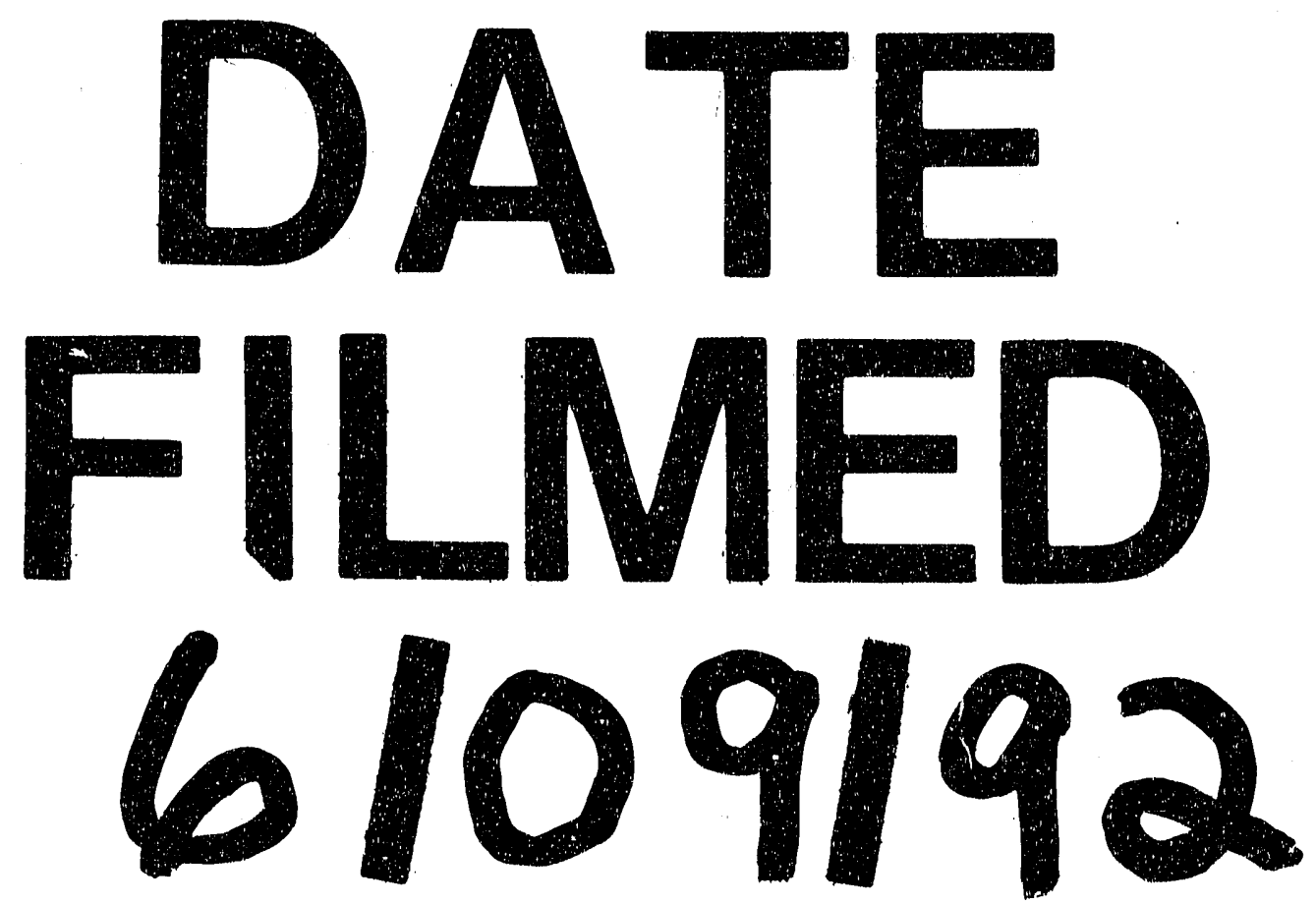


